\title{
HUBUNGAN STATUS GIZI DAN INDEKS PRESTASI DENGAN ASUPAN GIZI SEBAGAI FAKTOR RESIKO
}

\author{
Rahmi Nurmadinisia ${ }^{*}$, Yulia Anggraeni Hidayat $^{2}$ \\ 1. Program Studi S1 Kesehatan Masyarakat, Sekolah Tinggi Ilmu Kesehatan Raflesia, Depok-Indonesia \\ 2. Program Studi S1 Kesehatan Masyarakat, Sekolah Tinggi Ilmu Kesehatan Raflesia, Depok-Indonesia
}

*Korespondensi: Rahmi Nurmadinisia | Sekolah Tinggi Ilmu Kesehatan Raflesia |rahminur@gmail.com

\begin{abstract}
Abstrak
Pendahuluan: Penelitian ini bertujuan untuk menganalisis hubungan antara status gizi dan indeks prestasi mahasiswa STIKes Raflesia Depok. Prestasi akademik pada mahasiswa dipengaruhi oleh faktor yang bersumber dari internal dan eksternal setiap individu. Salah satu faktor internal yang mempengaruhi adalah status gizi. Gizi yang baik sangat penting untuk perkembangan mental, produktivitas serta prestasi akademik. Namun, peranan masing-masing faktor penentu tidak selalu sama dan tetap.

Metode: Metode penelitian menggunakan pendekatan kuantitatif cross sectional dengan jumlah sampel 140 orang mahasiswa. Pengambilan data primer dilakukan dengan pengukuran berat badan dan tinggi badan, dan pengisian kuesioner secara mandiri (self-administering questionnaire) sesuai pedoman pengisian kuesioner. Kuesioner $2 \times 24-$ hour of food recall digunakan untuk mengetahui asupan gizi mahasiswa. Data sekunder didapatkan berupa indeks prestasi mahasiswa. Analisis data menggunakan uji Chi Square dan regresi logistik.

Hasil: Hasil penelitian menunjukkan bahwa tidak ada hubungan antara status gizi dengan indeks prestasi mahasiswa. Dalam penelitian ini terdapat faktor lain yang lebih kuat sebagai penentu kesuksesan indeks prestasi mahasiswa.

Kesimpulan: Asupan Fe memiliki hubungan secara signifikan dengan indeks prestasi mahasiswa D3 Keperawatan STIKes Raflesia Depok.

Kata Kunci: Status gizi, Indeks prestasi, Mahasiswa, Asupan gizi, Asupan Fe.
\end{abstract}

Diterima 15 Maret 2021; Accepted 30 Juni 2021

\section{PENDAHULUAN}

Salah satu indikator keberhasilan yang dapat dipakai untuk mengukur keberhasilan suatu bangsa dalam membangun sumber daya manusia adalah Indeks Pembangunan Manusia (IPM) atau Human Development Index. Berdasarkan IPM maka pembangunan sumber daya manusia Indonesia belum menunjukkan hasil yang menggembirakan. Pada tahun 2017, IPM Indonesia menempati peringkat 113 dari 188 negara, yang merupakan peringkat lebih rendah dibandingkan peringkat IPM negara - negara tetangga. Indonesia menempati urutan ke 107 pada Human Development Indicators pada tahun 2020 dengan nilai indeks dari 189 Negara dan Wilayah (United Nations Development Programs, 2020). Berdasarkan penelitian Ayalew di Afrika bagian utara, 14,7\% dari peserta penelitian yang mengalami malnutrisi memiliki kemampuan akademik rendah prestasi di semester tersebut (Ayalew et al., 2020) .

Studi penelitian di Australia menunjukkan bahwastatus gizi dapat berkaitan dengan prestasi akademik yang dilambangkan dengan asupan makanan yang bergizi (Burrows, et al, 2017). Terdapat hubungan antara status pertumbuhan yang terganggu dengan kinerja serta hasil kecerdasan (Opoola, Adebisi and Ibegbu, 2017). Status gizi yang buruk adalah salah satu penyebab utama rendahnya kinerja akademik dan produktivitas (Opoola, Adebisi and Ibegbu, 2017). Kesehatan dan status gizi merupakan faktor penting untuk prestasi akademik di sekolahserta pada perguruan tinggi (Ghosh, 2013). Dalam konteks perguruan tinggi, promosi kesehatan bagi seluruh civitas akademika menjadi salah satu cara agar pembelajaran menjadi efektif (Ghosh, 2013).

Berdasarkan penelitian yang dilakukan oleh Kim (2010) di Bucheon Korea terdapat hubungan antara asupan gizi dengan prestasi akademik. Asupan gizi yang tunjukkan berupa energi, protein, lemak (PUFA), fosfor, potassium, danseng. Semakin banyak jumlah asupan zat gizi tersebut maka semakin tinggi prestasi akademik yang dicapai.

Berdasarkan hasil penelitian di India yang dilakukan pada mahasiswa, status gizi yang buruk mencerminkan prestasi akademik yang lebih rendah dibanding mereka dengan status gizi baik (Ghosh, 2012). Prestasi akademik pada remaja dipengaruhi oleh faktor-faktor yang berasal dari internal dan diri eksternal individu (Sembiring, et al., 2018). Studi penelitian di Indiajuga menyebutkan terdapat hubungan 
yang signifikan dari kinerja akademik dengan status gizi pada responden yaitu mahasiswa. Skor kinerja kognitif ditemukan lebih tinggi di antara responden dengan status gizi normal dibandingkan dengan malnutrisi (Priyadarshini \& Dash, 2017).

Berdasarkan hasil penelitian Sinurat (2018) terdapat hubungan yang linier antara status gizi dengan tingkat kecerdasan pada remaja di Medan, Indonesia (Sembiring, et al., 2018). Rismayanthi (2012) juga menunjukkan terdapat hubungan antara status gizi dengan tingkat kebugaran pada mahasiswa perguruan tinggi di Yogyakarta, Indonesia (Rismayanthi, 2012). Hasil penelitian Padriyani, et al., (2014) menunjukkan lebih dari 50\% remaja pada salah satu sekolah di Padang yang memiliki status gizi baik juga memiliki prestasi belajar yang baik (Padriyani, et al, 2014)

Hubungan antara status gizi dengan indeks prestasi akademik belum pernah dilakukan di STIKes Raflesia. Namun, berdasarkan hasil observasi masih terdapat beberapa mahasiswa dengan nilai indeks prestasi di bawah 2,75 yaitu sekitar 16,7\% pada mahasiswa Keperawatan tingkat 1. Jika dibandingkan pada penelitian sebelumnya dengan karakteristik subjek yang sama namun lokasi yang berbeda pula sekitar 20,1\% mahasiswa seluruh jenjang memiliki indeks prestasi di bawah 2,75 di Stikes yang berlokasi di propinsi Jawa Tengah (Nikmah, 2014). Selain itu, jika dibandingkan pada kampus kesehatan yang berlokasi di Lampung, sebanyak 28,9\% mahasiswa memiliki nilai IP yang kurang baik (Matin and Veria, 2013).

Penelitian ini bertujuan untuk melihat hubungan antara status gizi, asupan gizi makro (energi, protein, dan lemak) dan mikro (fosfor, potassium dan seng) serta melihat hubungan faktor resiko yang berhubungan dengan indeks prestasi akademik mahasiswa Keperawatan STIKes Raflesia Depok.

\section{METODE}

Desain penelitian cross sectional. Variabelpenelitian ini adalah Indeks Prestasi (IP)mahasiswa dengan dua kriteria yaitu baik (bila IP $\geq 3.00$ ) dan kurang (bila IP<3.00); Status Gizi (SG) mahasiswa dengan kriteria normal jika nilaiIMT $18-25 \mathrm{~kg} / \mathrm{m}^{2}$ \& tidak normal jika IMT $<18 \mathrm{~kg} / \mathrm{m}^{2}$ atau $>25 \mathrm{~kg} / \mathrm{m}^{2}$; Asupan Energi (AE) dengan kriteria Sesuai (<nilai median/hari) dan Tidak sesuai ( $\geq$ nilai median/hari); Asupan Lemak (AL) dengan kriteria Sesuai $(<=30 \%$ dari total energi/hari) dan Tidak Sesuai $(>30 \%$ dari total energi/hari); Asupan Protein (AP) dengan kriteria Sesuai $(>=93 \mathrm{~g} / \mathrm{hari})$ dan Tidak sesuai ( $<93 \mathrm{~g} / \mathrm{hari})$; Asupan $\mathrm{Fe}(\mathrm{AFe})$ dengan kriteria Sesuai (laki-laki $>9 \mathrm{mg} / \mathrm{hari}$;perempuan $>15 \mathrm{mg} / \mathrm{hari}$ ) Tidak Sesuai (laki-laki $<=9 \mathrm{mg} /$ hari;perempuan $<=15 \mathrm{mg} /$ hari); Asupan Seng (AS) dengan kriteria Sesuai $(>=12$ $\mathrm{mg} /$ hari kebutuhan AKG/hari) dan Tidak Sesuai (<12 mg/hari) ; Asupan Potasium (AP) dengan kriteria Sesuai ( $>=1000 \mathrm{mg} / \mathrm{hari})$ dan Tidak sesuai $(>1000 \mathrm{mg} / \mathrm{hari})$ ) dan Asupan Fosfor (AF) dengan kriteria Sesuai (>=4700 mg/hari) dan Tidak Sesuai ( $<4700 \mathrm{mg} / \mathrm{hari})$.

Penelitian ini menggunakan data primer melalui pengukuran status gizi dan pengisian kuesioner pada mahasiswa. Sampel penelitian ini adalah seluruh populasi mahasiswa D3 Keperawatan STIKes Raflesia berjumlah 178 orang. Darijumlah sampel tersebut ada 38 orang mahasiswa yang dapat diambil datanya karena sedang melakukan praktek lapangan di RS. Asupan lemak, protein, Fe, Zn, Potassium dan Fosfor mengacu pada standar Angka Kecukupan Gizi (AKG) (Hardinsyah, Riyadi and Napitupulu, 2012). Penelitian dilakukan pada bulan April 2019.

Instrumen yang digunakan pada penelitian ini adalah timbangan Seca, Microtoise, Form Food Recall $2 \times 24$ jam, dan buku foto makanan. Dalam pengambilan data, penelitian ini dibantu dua orang enumerator yang dipilih dan telah diberikan pelatihan terkait instrumen yangdiukur.

Analisis statistik pada penelitian ini terdiri dari dua tahap, yaitu analisis bivariat dengan uji Chi Square untuk melihat perbedaan antara status gizi, asupan energi, lemak, protein, $\mathrm{Fe}, \mathrm{Zn}$, potassium, dan fosfor responden menurut indeks prestasinya. Analisis selanjutnya adalah analisis multivariat dengan analisis regresi logistik untuk melihat hubungan antara status gizi dengan indeks prestasi setelah dikontrol variabel pengecoh (confounding), yaitu asupan energi, lemak, protein, $\mathrm{Fe}, \mathrm{Zn}$, potassium, dan fosfor. Dalam melakukan analisis bivariat dan multivariat digunakan Program SPSS ver. 21.

\section{HASIL}

Sebagian besar responden penelitian mempunyaiIP baik (67\%) dan berstatus gizi normal $(68,6 \%)$.

Tabel 1. Distribusi frekuensi Karakteristik Responden 


\begin{tabular}{ccc}
\hline Variabel & $\begin{array}{c}\text { Jumlah } \\
(\mathbf{n})\end{array}$ & $\begin{array}{c}\text { Persentase } \\
(\mathbf{\%})\end{array}$ \\
\hline IP mahasiswa & 94 & 67.1 \\
Baik & 46 & 32.9 \\
Kurang & & \\
Status Gizi & 96 & 68.6 \\
Normal & 44 & 31.4 \\
Tidak Normal & & \\
Asupan Energi & 46 & 67.1 \\
*Sesuai & 94 & 32.9 \\
Tidak Sesuai & & \\
Asupan Lemak & 20 & 85.7 \\
Sesuai & 120 & 14.3 \\
Tidak sesuai & & \\
Asupan Protein & 60 & 57.1 \\
Sesuai & 80 & 42.9 \\
Tidak Sesuai & & \\
Asupan Fe & 59 & 42.1 \\
Sesuai & 81 & 57.9 \\
Tidak Sesuai & & \\
Asupan Zn & 58 & 41.4 \\
Sesuai & 82 & 58.6 \\
Tidak Sesuai & & \\
Asupan Potassium & 46 & 67.1 \\
Sesuai & 94 & 32.9 \\
Tidak Sesuai & & \\
Asupan Fosfor & 108 & 77.1 \\
Sesuai & 32 & 22.9 \\
Tidak Sesuai & & \\
\hline & 46 & \\
\hline & & \\
\hline
\end{tabular}

Berdasarkan asupan gizi yang dikonsumsimahasiswa sudah sesuai atau melebihi kebutuhannya kecuali asupan Fe dan Zn yang sebagian besar masih dalam kategori cukup.

Tabel 2. Hubungan antara status gizi dan indeks prestasi

\begin{tabular}{|c|c|c|c|c|c|}
\hline \multirow{3}{*}{ Variabel } & \multicolumn{4}{|c|}{ IP mahasiswa } & \multirow{3}{*}{ P value } \\
\hline & \multicolumn{2}{|c|}{ Baik } & \multicolumn{2}{|c|}{ Kurang } & \\
\hline & $\mathrm{n}$ & $\%$ & $\mathrm{n}$ & $\%$ & \\
\hline \multicolumn{6}{|l|}{ Status Gizi } \\
\hline Normal & 68 & 70,1 & 29 & 29,9 & \\
\hline $\begin{array}{l}\text { Tidak Normal } \\
\text { AsupanEnergi }\end{array}$ & 28 & 65,1 & 15 & 34,9 & 0,697 \\
\hline Sesuai & 34 & 73,9 & 12 & 26,1 & \\
\hline Tidak Sesuai & 62 & 66,0 & 32 & 34,0 & 0,448 \\
\hline \multicolumn{6}{|l|}{ AsupanLemak } \\
\hline Sesuai & 15 & 75,0 & 5 & 25,0 & \\
\hline Tidak Sesuai & 81 & 67,5 & 39 & 32,5 & 0,683 \\
\hline \multicolumn{6}{|l|}{ AsupanProtein } \\
\hline Sesuai & 46 & 76,7 & 14 & 23,3 & \\
\hline Tidak Sesuai & 50 & 62,5 & 30 & 37,5 & 0,109 \\
\hline \multicolumn{6}{|l|}{ Asupan Fe } \\
\hline Sesuai & 48 & 81,4 & 11 & 11,6 & \\
\hline Tidak Sesuai & 48 & 59,3 & 33 & 40,7 & 0,009 \\
\hline
\end{tabular}




$\begin{array}{llllll}\text { Asupan Zn } & & & & & \\ \quad \text { Sesuai } & 38 & 65,5 & 20 & 34,5 & \\ \quad \text { Tidak Sesuai } & 58 & 70,7 & 24 & 29,3 & 0,638 \\ \text { Asupan Potassium } & & & & & \\ \quad \text { Sesuai } & 33 & 71,7 & 13 & 28,3 & \\ \quad \text { Tidak Sesuai } & 63 & 67,0 & 31 & 33,0 & 0,711 \\ \text { Asupan Fosfor } & & & & & \\ \quad \text { Sesuai } & 75 & 69,4 & 33 & 30,6 & \\ \quad \text { Tidak Sesuai } & 21 & 65,6 & 11 & 34,4 & 0,848\end{array}$

${ }^{1}$ Nilai signifikansi berada pada p value $<0,05$.

Berdasarkan hasil uji Chi Square diketahui bahwa hanya asupan Fe $(\mathrm{p}<0,05)$ yang berhubungan dengan indeks prestasi dan asupan protein berhubungan dengan indeks prestasi pada $\alpha=5 \%(p=0,109)$.

Tabel 3. Hasil regresi logistik Model FR

\begin{tabular}{ccc}
\hline Variabel & Nilai OR & p Value \\
\hline Fe & 7,247 & 0,0001 \\
Zn & 0,228 & 0,009 \\
Fosfor & 0,212 & 0,084 \\
\hline
\end{tabular}

Berdasarkan hasil analisis multivariat regresilogistik model Faktor risiko, terdapat empat variabel yang memiliki hubungan dengan indeks prestasi mahasiswa D3 Keperawatan STIKes Raflesia Depok tahun 2019. Asupan Fe menjadi faktor risiko terbesar yang memiliki hubungandengan indeks prestasi mahasiswa setelah dikontrol dengan asupan Zn, asupan fosfor serta status gizi mahasiswa D3 Keperawatan STIKes Raflesia Depok.

\section{PEMBAHASAN}

Status gizi merupakan determinan utama dalam pertumbuhan otak, yang berarti bahwa status gizi memiliki peranan penting dalam membentuk kecerdasan. Kekurangan atau kelebihan zat gizi bisa mempengaruhi terjadinya learning disabilities (gangguan belajar) yang dapat berpengaruh langsung terhadap pencapaian prestasi belajar. Namun, jika dilihat dari hasil penelitian ini status gizi tidak berpengaruh terhadap prestasi belajar mahasiswa. Walaupun dasar teori menjelaskan bahwa status gizi berhubungan dengan prestasi seseorang, akan tetapi masih banyak faktor internal lain yang juga berhubungan dengan prestasi mahasiswa, yang tidak dijadikan variabel dalam penelitian ini dan tidak dilakukan pengukuran terhadap variabel lain tersebut, yaitu intelegensi, motivasi, cara belajar Rendahnya status gizi akan membawa dampak negatif pada peningkatan kualitassumber daya manusia. Kekurangan gizi berhubungan erat dengan pencapaian prestasi akademik yang rendah (Maku, 2018).

Namun, berdasarkan hasil penelitian yang telah dilakukan tidak terdapat hubungan antara status gizi dengan indeks prestasi mahasiswa. Hal ini sejalan dengan penelitian Trockel, et al. (2010) yang menyebutkan tidak ada hubungan signifikanantara status gizi dengan IPK, namunberdasarkan studi yang juga dilakukan mahasiswa yang mengkonsumsi buah dua ataulebih per hari memiliki nilai indeks prestasi yang lebih baik. Penelitian yang sama juga menunjukkan tidak ada korelasi/hubungan yang berarti antara status gizi dengan Indeks Prestasi Kumulatif mahasiswa (Herdiani, Novera, Handayani, 2008).

Hal ini berbanding terbalik dengan penelitian Ghosh \& Saha (2012) yang menyatakan status gizi memiliki peranan penting dan berpengaruh pada pencapaian prestasi pendidikan. Meskipun hingga saat ini belum jelas bagaimana zat gizi mendukung atau menghambat pencapain akademik, namun kondisi kesehatan yang buruk serta malnutrisi dapat mempengaruhi kemampuankognitif seseorang (Ghosh \& Saha, 2012). Tidak adanya kaitan antara status gizi dengan indeks prestasi kemungkinan dikarenakan masalah gizi pada mahasiswa masih tergolong pada tahap ringan sehingga tidak terlalu mengganggu kemampuan belajarnya. Hasil penelitian ini juga menunjukkan bahwa status gizi kurang tidak termasuk sebagai salah satu faktor penentu hasil belajar, jadi mahasiswa yang mempunyai status gizi baik belum tentu mendapatkan prestasi belajar berupa indeks prestasi kumulatif (IPK) yang baik. Status gizi merupakan determinan utama dalam pertumbuhan otak, yang berarti bahwa status gizi memiliki peranan penting 
dalam membentuk kecerdasan. Kekurangan atau kelebihan zat-zat esensi gizi bisa mempengaruhi terjadinya learning disabilities (gangguan belajar) yang dapat berpengaruh langsung terhadap kesuksesan prestasi belajar. Namun, jika dilihat dari hasil penelitian ini status gizi tidak berpengaruh terhadap IPK mahasiswa. Ariyanto (2019) mengungkapkan bahwa faktor-faktor yang mempengaruhi proses dan hasil belajar, secaragaris besar dapat dibagi kepada tiga bagian, yaitu faktor internal (intelegensia, bakat, minat, motivasi, status gizi), faktor eksternal (kurikulum, faktor dosen pengajar, lingkungan keluarga, sarana dan pra sarana pendukung kegiatan belajar), dan faktor pendekatan belajar. Artinya, status gizi tidak menjadi faktor penentu dalam keberhasilan mahasiswa mencapai hasil prestasi belajar yang baik, dengan usia mahasiswa yang berada pada tingkat remaja, diduga ada banyak faktor selain status gizi yang lebih kuat mempengaruhi prestasi belajar mahasiswa seperti intelegensi, motivasi, cara belajar, serta bakat. Dalam penelitian ini ada faktor lain yang lebih spesifik sebagai penentu pencapaian IPK mahasiswa yaitu asupan Fe.

\section{Hubungan antara asupan energi, lemak dan protein dengan indeks prestasi mahasiswa}

Berdasarkan hasil penelitian, tidak terdapat hubungan antara asupan energi dengan indeks prestasi mahasiswa program studi D3 Keperawatan STIKes Raflesia Depok. Hal ini tidak sejalan dengan penelitian Apriyanti (2016), yang mengatakan asupan energi memiliki hubungan dengan indeks prestasi mahasiswa. Kandungan zat gizi yang tidak mencukupi dari makanan yang dikonsumsi dalam jangka waktu lama dapat menyebabkan perubahan metabolisme di dalam tubuh . Ketidakmatangan dan ketidaksempurnaan struktur kimia dalam otak, serta pengurangan jumlah sel otak dapatdikarenakan adanya kondisi kekurangan gizi yang sifatnya kronis dan berat. Sehingga keadaan ini mempengaruhi perkembangan kecerdasan otak. Mekanisme status gizi hingga prestasi belajar rendah dimulai dari anak dengan status gizi yang tidak baik (malnutrisi) akibat rendahnyaasupan makanan (Apriyanti, 2016).

Dalam lambung makanan hanya mampu bertahan selama 6-8 jam, setelah itu lambung kosong karena sari-sari makanan telah diserap dan diedarkan keseluruh tubuh, sehingga akan terjadi pemecahan glikogen untuk memenuhi kebutuhannya, sehingga terjadi deplesi jaringan yang kemudian menyebabkan perubahan biokimia, perubahan fungsional dan perubahan anatomis tubuh (Apriyanti, 2016). Penelitian di Chili menunjukkan, konsumsi makanan padat energi, rendah serat dan tinggi lemak yangberlebih berhubungan dengan penurunan performa akademik pada siswa usia 16 tahun di Chili (Correa-Burrows, et al, 2016).

Asupan lemak juga tidak memiliki hubungan dengan indeks prestasi mahasiswa. Hal ini sejalandengan penelitian Purnakarya, et al. (2011), bahwa lemak dan protein tidak memiliki hubungan secara signifikan dengan indeks prestasi mahasiswa. Terdapat banyak faktor yang mempengaruhi prestasi belajar diantaranya adalah faktor psikologis siswa, dimana terdiri dari kecerdasan dan motivasi dalam diri siswa itu sendiri. Menurut Sety, et al. (2005), taraf kecerdasan meliputi beberapa aspek salah satunya diantaranya yang berpengaruh terhadap prestasi belajar adalah daya ingat. Dalam penelitian ini, faktor internal lain seperti intelegensi, motivasi, cara belajar dan bakat yang mempengaruhi indeks prestasi mahasiswa tidak dilakukan pengumpulan data. Perbedaan asupan yang tidak terlalu signifikan kemungkinan menjadi faktor yang mengakibatkan tidak adanya hubungan antara asupan energi dengan indeks prestasi mahasiswa.

\section{Hubungan antara asupan Zn dan fosfor dengan indeks prestasi mahasiswa}

Asupan $\mathrm{Zn}$ dan Fosfor diketahui tidak berhubungan dengan indeks prestasi mahasiswa. Penelitian ini sejalan dengan penelitian Putu (2017) yaitu tidak terdapat perbedaan antara asupan Zn dengan IPK mahasiswa. Tidak adanya hubungan dalam penelitian ini disebabkan oleh adanya faktor lain yaitu asupan Fe Hal ini juga sejalan dengan hasil penelitian Handayani berupatidak adanya hubungan yang signifikan antara asupan seng dengan prestasi belajar (Handayani, Nurlaili, et al,. 2020).

Pemenuhan kebutuhan zat gizi khususnya pada pemenuhan zat gizi mikro memiliki peranan yang esensial dalam perkembangan otak. Seng merupakan salah satu mikronutrien yang berkaitan dengan protein dan berfungsi sebagai struktur sel otak dan neurotransmiter yang terlibat dalam memori otak sehingga dapat berpengaruh terhadap perkembangan kognitif dan prestasibelajar (Putu,2017) .

\section{Hubungan antara asupan Fe dengan indeksprestasi mahasiswa}

Hasil analisis menunjukkan asupan $\mathrm{Fe}$ menjadisatu-satunya faktor yang memiliki hubungandengan indeks prestasi mahasiswa dengan nilai $\mathrm{p}<0,005$. Dalam model terakhir dari analisis ini menunjukkan 
nilai OR sebesar 7,4x, yang artinya mahasiswa dengan asupan Fe yang baik berpeluang 7,4 kali akan memiliki indeks prestasiyang baik dibandingkan dengan mahasiswa dengan asupan Fe yang kurang.

Beberapa penelitian lain juga menunjukkan adanya kaitan antara asupan Fe memiliki hubungan dengan konsentrasi yang mempengaruhi prestasi mahasiswa, diantaranya Penelitian Astiandani (2015) menunjukkan anemia pada remaja putri berisiko 1,875 kali lipat memperoleh prestasi belajar yang rendah dibandingkan remaja putri yang tidak anemia dan Penelitian Hasanah (2015) menunjukkan tingkat keparahan kekurangan asupan $\mathrm{Fe}$ dalam jumlah besar berdampak pada rendahnya nilai biokimia yang diperoleh mahasiswa (Hasanah, 2015).

Menurut World Health Organization (WHO) batasan umur remaja adalah 12 sampai 24 tahun. Pada masa ini remaja memiliki keunikan gayahidup sehingga berdampak pada masalah gizi yang dialami salah satunya anemia. Keunikan gaya hidup tersebut seperti pola makan kurang tepat untuk menjaga penampilan, kesukaan berlebihan pada makanan tertentu, menstruasi dan pemahaman gizi yang keliru (Retno, Dumilah and Sumarmi, 2017). Fe merupakan bagian penting dari hemoglobin, myoglobin dan enzim. Fe juga merupakan unsur penting dalam produksi dan pemeliharaan mielin serta mempengaruhi aktivitas saraf Salah satu peranan penting zat besi $(\mathrm{Fe})$ dalam tubuh yaitu sebagai kofaktor yang digunakan untuk mengaktifkan enzim Mono Amin Oksidase (MAO) yang berada pada otak yang berfungsi untuk meningkatkan daya konsentrasi.

Dalam penelitian ini status gizi tidak berhubungan dengan indeks prestasi mahasiswa, namun lebih mengarah spesifik pada asupan Fe. Sehingga dari seluruh faktor risiko yang diteliti hanya asupan $\mathrm{Fe}$ yang berhubungan denganindeks prestasi mahasiswa, terrmasuk hipotesa awal yaitu status gizi. Faktor-faktor apa saja yang mempengaruhi asupan Fe tidak dimasukkan dalam penelitian ini, termasuk proses absorpsi Fe dalam tubuh. Oleh karena itu, diperlukan penelitian lebih lanjut sehingga dapat diketahui faktor yang dapat meningkatkan absorpsi $\mathrm{Fe}$ dan juga pemberian intervensi yang tepat kepada mahasiswa sehingga dapat meningkatkan konsentrasi serta peningkatan prestasi belajar mahasiswa.

\section{KESIMPULAN}

Penelitian ini mendapatkan tidak terdapat hubungan antara status gizi, asupan energi, lemak, protein, Fe, Zn, Potassium, dan Fosfor dengan indeks prestasi pada mahasiswa program studi D3 Keperawatan STIKes Raflesia Depok. Asupan Fe menjadi faktor risiko terbesar yangmemiliki hubungan dengan indeks prestasi mahasiswa setelah dikontrol dengan asupan $\mathrm{Zn}$, asupan fosfor serta status gizi mahasiswa D3 Keperawatan STIKes Raflesia Depok. Status gizi memiliki interaksi dengan asupan fosfor.

\section{UCAPAN TERIMA KASIH}

Terima kasih kepada pihak STIKes Raflesia yangmembantu berjalannya penelitian ini. Terimakasih juga kepada enumerator yang telah membantu dalam pengambilan data penelitian.

\section{REFERENSI}

Almatsier, S. (2003). Prinsip Dasar Ilmu Gizi. PT. Gramedia Pustaka Utama, Jakarta.

Apriyanti, D. (2016) 'Hubungan Asupan protein, Status Gizi Terhadap Prestasi Belajar Mahaasiswa di Politeknik Kesehatan Kemenkes Tasikmalaya Media Informasi, 12(1), pp.96- 103.

Ayalew, M. et al. (2020) 'Nutritional Status and Educational Performance of School-Aged Children in Lalibela Town Primary Schools ,Northern Ethiopia', 2020.

Burrows, Tracy L, Whatnall, Mgean C, Patterson, Amanda, and H. M. (2017) 'Associations between Dietary Intake and Academic Achievement in College Students: A Systematic Review', Healthcare, 5(4), p. 60. doi: 10.3390/healthcare5040060.

Cerika Rismayanthi (2012) 'Relation Among Nutrition Status and Physical Fitness Level', Jurnal Kependidikan, Volume 42, pp. 29-38.

Correa-Burrows, P. et al. (2016) 'Nutritional qualityof diet and academic performance in Chileanstudents [Qualité nutritionnelle de l'alimentationet résultats scolaires des lycéens chiliens] [Calidad nutricional de la dieta y rendimiento académico de los estudiantes chilenos]', Bulletin of the World Health Organization, 94(3), pp.185-192. doi: 10.2471/BLT.15.161315.

Ghosh, S. and Saha, H. (no date) 'The Role of Adequate Nutrition on Academic Performance of College Students in North Tripura', 3(3), pp. 41-53.

Handayani, Nurlaili, Jamil, Muhammad Dawam, Palupi, I. R. (2020) 'Faktor Gizi dan Prestasi Belajar 
Siswa Sekolah Menengah Kejuruan', 4(1), pp. 69-78.

Hardinsyah, Riyadi, H. and Napitupulu, V. (2012) 'Kecukupan energi, protein, lemak dan karbohidrat', Departemen Gizi FK UI, 2004(Wnpg 2004), pp. 1-26.

Hasanah, U. (2015) 'Hubungan Anemia Defisiensi Zat Gizi Besi dengan Hasil Belajar BiokimiaMahasiswa Biologi FMIPA UNIMED Tahun 2014', 13(25), pp. 29-36.

Herdiani, Novera, Handayani, D. (2008) 'Hubungan status gizi dengan indeks prestasi kumulatif mahasiswa di prodi ilmu kesehatan masyarakat unusa', pp. 39-51.

Maku, Adrianus, Mendri, Ni Ketut, Devianto, A. (2018) 'Hubungan Antara Status Gizi dengan Prestasi Belajar Anak SD di SDN Ngringin Depok, Sleman Yogyakarta', 7(1), pp. 1-8.

Matin, S. S. and Veria, V. A. (2013) 'Body Mass Index ( Bmi ) Sebagai Salah Satu Faktor Yang Berkontribusi Terhadap', Visikes, 12, pp. 163-169.

Nikmah, N. (2014) 'Faktor-Faktor yang Mempengaruhi Nilai Indeks Prestasi Kumulatif (IPK) Mahasiswa Program Studi DIII Kebidanan STIKES Insan Se Agung Bangkalan', 1 (1) Publikasi Jurnal Web Nurun.[cited November 2018]. Available from: https://www. scribd.com/doc/316678934/No-4Publikasi-Jurnal-Web-Nurun..

Opoola, F., Adebisi, S. and Ibegbu, A. (2017) 'The study of nutritional status and academic performance of primary school children in Zaria, Kaduna State, Nigeria', Annals of Bioanthropology, 4(2), p. 96. doi: 10.4103/2315-7992.204680.

Padriyani, S. O. and dkk (2014) 'Hubungan Status Gizi dengan Prestasi Belajar pada Siswa-Siswi SMAN 1 Padang Tahun Ajaran 2013/2014', Kesehatan Andalas, 3(3), p. 473.

Priyadarshini, V. and Dash, L. (2017) 'Influence of Nutritional Status on Cognition and Academic Performance of College Students', International Journals of Medical Sciences, 10(1and2), pp. 14-18. doi: 10.15740/has/ijms/10.1and2/14-18.

Retno, P., Dumilah, A. and Sumarmi, S. (2017) 'Hubungan Kejadian Anemia Dengan PrestasiBelajar Siswi Di SMP Unggulan Bina Insani The Association Between Anaemia Incident and Student Learning Achievement At Bina Insani Junior High School', pp. 331-340. doi: 10.20473/amnt.v1.i4.2017.331340 .

Sembiring, T. et al. (2018) 'Correlation of nutritional status with academic achievement in adolescents', IOP Conference Series: Earth and Environmental Science, 125, p. 012226. doi: 10.1088/17551315/125/1/012226.

WHO. (1995). Physical status: The use and interpretation of anthropometry. Switzerland: WHO Library. https://doi.org/854

WHO. (2000). Nutrition For Health and Development. 